\title{
Het hart in balans
}

Citation for published version (APA):

Glatz, J. F. (2004). Het hart in balans. Maastricht University. https://doi.org/10.26481/spe.20040514jg

Document status and date:

Published: 14/05/2004

DOI:

10.26481/spe.20040514jg

Document Version:

Publisher's PDF, also known as Version of record

\section{Please check the document version of this publication:}

- A submitted manuscript is the version of the article upon submission and before peer-review. There can be important differences between the submitted version and the official published version of record.

People interested in the research are advised to contact the author for the final version of the publication, or visit the DOI to the publisher's website.

- The final author version and the galley proof are versions of the publication after peer review.

- The final published version features the final layout of the paper including the volume, issue and page numbers.

Link to publication

\footnotetext{
General rights rights.

- You may freely distribute the URL identifying the publication in the public portal. please follow below link for the End User Agreement:

www.umlib.nl/taverne-license

Take down policy

If you believe that this document breaches copyright please contact us at:

repository@maastrichtuniversity.nl

providing details and we will investigate your claim.
}

Copyright and moral rights for the publications made accessible in the public portal are retained by the authors and/or other copyright owners and it is a condition of accessing publications that users recognise and abide by the legal requirements associated with these

- Users may download and print one copy of any publication from the public portal for the purpose of private study or research.

- You may not further distribute the material or use it for any profit-making activity or commercial gain

If the publication is distributed under the terms of Article $25 \mathrm{fa}$ of the Dutch Copyright Act, indicated by the "Taverne" license above, 
Ob4 
Het hart in balans 


\section{Colofon}

Basisontwerp en realisotie: Unigraphic, Universiteit Moostricht.

fotografie omslag: Hons Patelski

Object: De waterdrager, uit de collectie figurines 'Oude Ambochten en Konsten' in tin van de N.V. Koninklijke Metaalwarenfabrieken Daalderop, Tiel. Ontworpen door kunstenaor Michiel Warbroek (rond 1975). Vrij naar Johannes Luyken en diens zoon Caspaares, die ruim zoo jaor geleden de beroepen vereeuwigden in hun 'Verbeeldingen van ambachten, konsten, handelingen en bedrijuen:

ISBN 90-5681-203-3

NUR 870

Alle rechten voorbehouden. Niets uit deze uitgove mag worden verveelvoudigd, opgeslogen in een geautomatiseerd gegevensbestond of openbaor gemaakt, zonder voorafgaande schriftelijke toestemming van de auteur of uitgever. 
Een hart voor balans

houdt het hart in balans

$$
\begin{aligned}
& P \mu N .2 \% 0113 \text { 4q9 } \\
& \text { this ats } \\
& \text { Enoranis : at } \\
& 0500154
\end{aligned}
$$

Ter nagedachtenis aan mijn vader

Voor Marie-Adele, Eline en Barbara 
Meneer de Rector Magnificus, vertegenwoordigers van de Nederlandse Hartstichting, collegae, familie en vrienden.

\section{Zeer gewaardeerde toehoorders.}

Precies een halve eeuw geleden, in 1954, publiceerde de Amerikaanse medisch onderzoeker Richard Bing in het wetenschappelijke tijdschrift American Journal of Medicine het verslag van een experimentele studie naar de energiestofwisseling van de hartspier.' Richard Bing deed de aanname dat de hartspier de voor zijn samentrekking benodigde energie zou betrekken uit verschillende in de bloedbaan aanwezige brandstoffen, waaronder glucose en vetzuren. Dat glucose een belangrijke brandstof is voor het hart was al vele jaren eerder aangetoond; het gebruik van vetzuren was nog niet systematisch onderzocht. Bing maakte gebruik van een nieuwe techniek waarbij bloedmonsters werden genomen uit de aanvoerende en de afvoerende bloedvaten van het menselijke hart. Door in deze bloedmonsters de hoeveelheden van de verschillende brandstoffen en van zuurstof te bepalen kon hij achterhalen welke stoffen waren opgenomen. In deze studie toonde hij voor het eerst aan dat de menselijke hartspier in zijn energiebehoefte voorziet door niet alleen glucose maar ook vetzuren op te nemen en te verbranden. Sterker nog, hij toonde aan dat vetzuren kwantitatief zelfs de belangrijkste energiebron zijn.

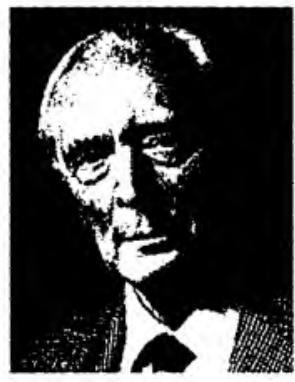

Richard J. Bing

Met deze publicatie legde Richard Bing voor het eerst de relatie tussen vetzuren en de energiehuishouding van het hart onomstotelijk vast. Bing kan dan ook beschouwd worden als de nestor van de vetzuurstofwisseling in de hartspier. Momenteel is hij 94 jaar oud, woont in Californië en is nog altijd actief in het hartonderzoek. ${ }^{2}$ 
Dat we nu, vijftig jaar later, een veel beter inzicht hebben in de betekenis van vetzuren voor het hart in het algemeen, en voor de cardiale energiehuishouding in het bijzonder, laat zich raden. In deze rede wil ik deze ontwikkelingen vanuit historisch perspectief schetsen en probeer ik aan te geven in welke richting dit veld zich in de toekomst naar mijn mening zal ontwikkelen en welke bijdrage ik daaraan zou willen leveren. Ik hoop u ervan te kunnen overtuigen dat we momenteel juist aan het begin staan van de toepassing van de op dit terrein verworven kennis voor de behandeling van hart-en vaatziekten. In het tweede deel van deze rede wil ik ook aandacht vragen voor twee andere zaken waarmee de universitaire onderzoeker wordt geconfronteerd: de onderzoeksorganisatie en het onderwijs.

\section{Voedingsstoffen voor het hart}

Laten we eerst teruggaan in de geschiedenis. Hoewel de centrale plaats van het hart in de circulatie al bij de oude Grieken bekend was, duurde het nog tot de zestiende eeuw dat werk van de Italiaanse anatoom Vesalius (1514-1564, Padua) het hart en de bloedvaten anatomisch in kaart bracht (Tabulae Anatomicae). Daarna was het de Engelsman William Harvey (1578-1657) die redeneerde dat de bloedsomloop het gevolg was van de pompwerking van het hart. Met zijn werk Anatomical treatise on the motion of the heart and blood in animals, dat verscheen in 1628 , legde hij de basis voor ons begrip van de werking en betekenis van het hart.

De taak van het hart als 'rode motor' is relatief eenvoudig: het pompt het bloed door het menselijk lichaam. Op deze wijze wordt het gehele lichaam van zuurstof en voedingsstoffen voorzien en kunnen geproduceerde kooldioxide en afvalstoffen worden afgevoerd. Het spreekt voor zich dat voor zo'n belangrijke functie en continue activiteit ook het hart zelf voortdurend energie nodig heeft. Verrassend genoeg maakte men zich er lange tijd niet druk over waar deze energie vandaan zou komen. Welke voedingsstoffen zijn belangrijk? Hoe wordt hun verbruik gereguleerd?

De uit onze voeding afkomstige energieleverende stoffen zijn glucose, vetzuren en aminozuren. Ze worden aan de verschillende weefselcellen aangeboden, zo ook aan de hartspiercellen. De energieproductie vindt plaats in de mitochondriën van de cel, die dus als energiecentrales kunnen worden beschouwd (Fig. 2). De daarbij vrijkomende chemische energie wordt opgeslagen in de energierijke verbinding adenosinetri- 
fosfaat (ATP). Hiervoor is zuurstof nodig; de afvalproducten zijn kooldioxide en water. In afwezigheid van zuurstof en in cellen zonder mitochondriën kan ook energie worden geproduceerd, maar alleen uit glucose dat dan wordt omgezet in melkzuur; dit levert relatief veel minder energie op. Melkzuur kan, in aanwezigheid van zuurstof, verder worden verbrand en is dus zelf ook een brandstof.

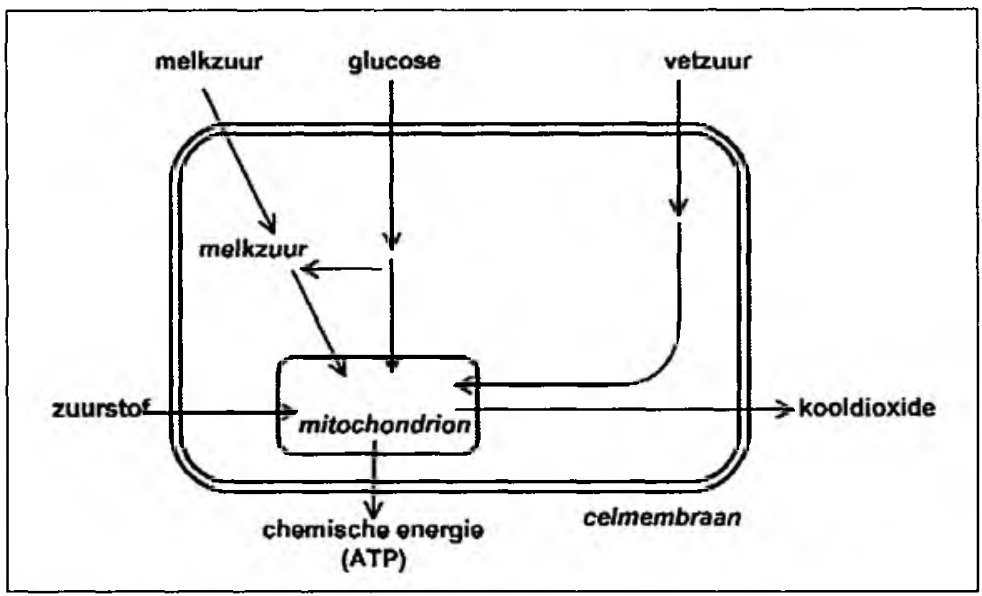

Fig. 2. Energieproductie in de hartspiercel.

Pas aan het begin van de vorige eeuw begon men zich af te vragen welke brandstoffen en in welke onderlinge verhouding door het hart worden gebruikt. Onderzoek aan het geïsoleerde hart van proefdieren leerde dat glucose en melkzuur belangrijke substraten waren en hun relatieve verbruik werd bepaald door de verhouding waarin deze stoffen in het bloed worden aangeboden. Melkzuur is afkomstig van rode bloedcellen, die geen mitochondriën bevatten en voor hun energievoorziening op de omzetting van glucose in melkzuur zijn aangewezen, en van skeletspiercellen. De verwerking ervan door de hartspier is een prachtige illustratie van een nuttige samenwerking tussen verschillende organen. Deze verklaring leek afdoende; de voedingsstoffen van het hart zijn nu bekend.

Toen men echter ook het zuurstofverbruik van de hartspier in de beschouwing betrok, bleek dit aanzienlijk hoger dan met de verbranding van glucose en melkzuur kon worden verklaard. Dit deed vermoeden dat dit niet de enige energiebronnen zijn, maar dat nog andere 
brandstoffen worden gebruikt, bijvoorbeeld vetzuren. Deze redenering is al in 1914 beschreven door Evans, ${ }^{3}$ en in 1930 met maat en getal bekrachtigd door Visscher en Mulder, ${ }^{4}$ die lieten zien dat het onverklaarbare deel van het zuurstofverbruik zelfs meer dan 50\% kon bedragen. Maar, zoals genoemd, duurde het nog tot de jaren vijftig voordat Richard Bing de energiehuishouding in kaart bracht." Onder normale omstandigheden is het aandeel van vetzuren ongeveer $60 \%$ (Fig. 3). Na een vetrijke maaltijd, wanneer het vetzuuraanbod in het bloed toeneemt, haalt het hart ongeveer $80 \%$ van zijn energie uit vetzuren. Kortom, het beeld was nu compleet: de hartspier is een omnivoor, een alleseter, gebruikt voor zijn energievoorziening de in de bloedbaan circulerende voedingsstoffen op geleide van hun beschikbaarheid. Door deze veelzijdigheid is de zo belangrijke energieproductie van het hart, en daarmee de pompfunctie, optimaal gewaarborgd.

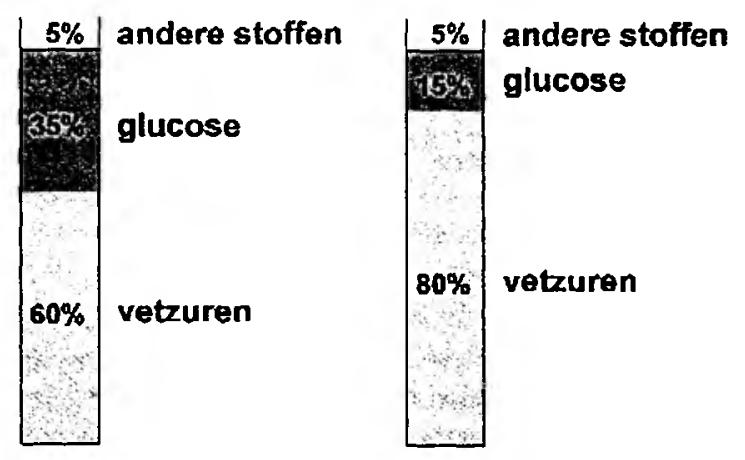

normale voeding

vetrijke voeding

Fig. 3. Brandstoffen van het hart.

In de daaropvolgende jaren zijn deze bevindingen door anderen bevestigd. Ook is gezocht naar het mechanisme waarmee de cel regelt dat veranderingen in aanbod aan voedingsstoffen worden vertaald naar veranderingen in verbruik ervan. Zo is, o.a. door de Zuidafrikaan Lionel Opie, ${ }^{6}$ gevonden dat er een voorkeursbehandeling is: melkzuur wordt met voorrang verbrand, gevolgd door vetzuren, daarna glucose. De Engelse onderzoeker Sir Philip Randle beschreef in 1963 hoe glucose en vetzuren in de cel op elkaar inwerken en hoe daarmee wordt bewaakt dat de cel precies zoveel energie produceert als het op dat moment 
nodig heeft en dit doet op de meest efficiënte wijze. ${ }^{2 .}$ Een voorkeursbehandeling van vetzuren ten opzichte van glucose is zeer zinvol. Immers, vetzuren hebben per gram een grotere energieinhoud (vetzuren $9.0 \mathrm{~kJ} / \mathrm{g}$; glucose $4.2 \mathrm{~kJ} / \mathrm{g}$ ), en het preferentieel gebruik ervan door het hart houdt meer glucose beschikbaar voor de hersenen die voor hun energievoorziening geheel op deze brandstof zijn aangewezen.

\section{Regulatie van de cellulaire opname van brandstoffen}

Stilzwijgend hebben we in onze beschouwing een belangrijk proces overgeslagen. Zou het niet verstandig zijn dat de cel veranderingen in het verbruik van voedingsstoffen niet alleen in de mitochondriën reguleert maar ook de cellulaire opname daarop zou aanpassen?

Pas in de jaren tachtig van de vorige eeuw is er aandacht voor de cellulaire opname, dat wil zeggen het transport van voedingsstoffen van het extracellulaire milieu over de celmembraan naar het intracellulaire milieu. Hoe worden de verschillende stoffen opgenomen? Is hun opnamesnelheid louter afhankelijk van het aanbod, of wordt de opname zelf gereguleerd? Om dit transport te kunnen begrijpen is het belangrijk inzicht te hebben in de opbouw en samenstelling van de celmembraan en in de chemische eigenschappen van de verschillende brandstoffen.

De celmembraan is opgebouwd uit fosfolipiden, dit zijn vetachtige stoffen die zelf weer bestaan uit een hydrofiele - waterminnende - stof waarin twee hydrofobe - waterafstotende - stoffen, namelijk vetzuren, chemisch zijn gekoppeld (Fig. 4). Door fosfolipiden in twee naast elkaar gelegen lagen te rangschikken, zodanig dat de hydrofobe zijden naar elkaar toe wijzen, ontstaat een dubbele-laagstructuur die niet doordringbaar is voor water. Een afscheiding tussen extra- en intracellulaire vloeistof is hiermee gerealiseerd. Door de hydrofobe aantrekkingskrachten van de fosfolipiden onderling wordt deze dubbele laagstructuur in stand gehouden. Op grond van deze structuur is al in te zien dat hydrofiele stoffen de membraan niet kunnen passeren, maar dat hydrofobe of vetachtige stoffen wel in de celmembraan kunnen binnendringen.

Laten we eerst kijken naar glucose, dat vanwege zijn hydrofiele karakter niet door de celmembraan heen kan. Rond 1980 heeft men ontdekt dat er in de membraan specifieke eiwitten zijn die functioneren als doorlaatpost voor glucosemoleculen. ${ }^{9}$ Deze glucose transporteurs, kortweg GLUT eiwitten genoemd, kunnen we zien als openingen in de cel- 


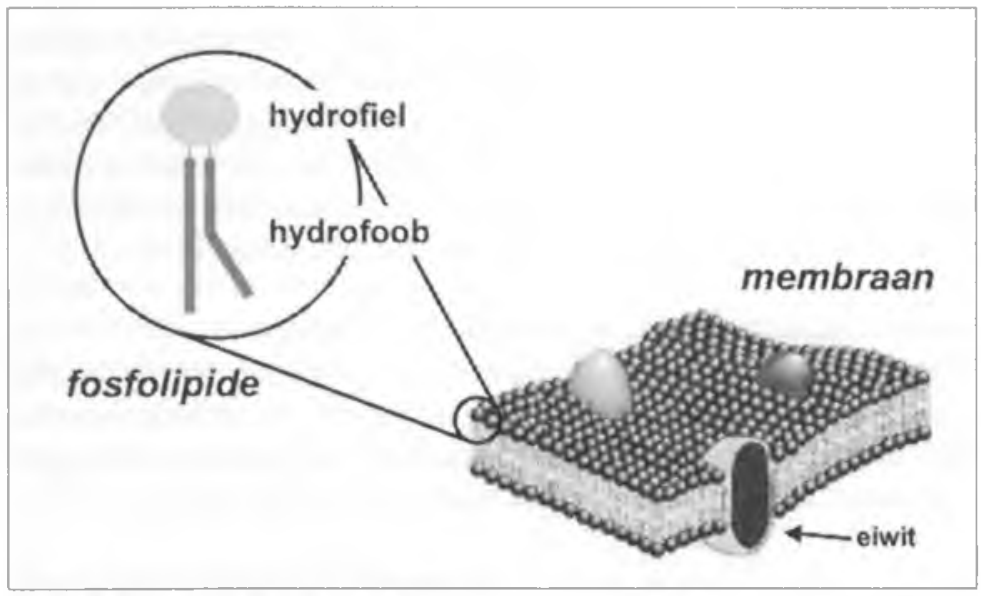

Fig. 4. Opbouw van de celmembraan

membraan waardoorheen alleen glucose - geen andere verbindingen van de ene naar de andere waterige ruimte kunnen bewegen. Bij voldoende aanvoer van buitenaf en verbruik in de cel zal er dus netto glucose van buiten naar binnen stromen. Dit opnameproces moet natuurlijk goed geregeld worden. De deuren moeten niet altijd openstaan. enerzijds om te voorkomen dat meer glucose wordt opgenomen dan de cel op dat moment aan kan, anderzijds om de hoeveelheid glucose in het bloed niet teveel te doen dalen om ook de hersenen te kunnen bedienen. Voor deze regulatie heeft de natuur een ingenieus systeem bedacht. De hoeveelheid glucose-transporteiwitten in de membraan kan namelijk naar gelang de behoefte vrijwel momentaan worden aangepast. In een speciaal compartiment in de cel, de endosomen, liggen transporteiwitten opgeslagen, die op afroep naar de membraan worden gebracht om aldus glucose opname mogelijk te maken. Als de behoefte aan glucose afneemt, verhuizen de eiwitten weer naar hun intracellulaire opslagplaats (Fig. 5). Met dit translocatiemechanisme is een nauw. keurig instelbare en efficiënte regeling van de glucoseopname mogelijk.

De GLUT eiwitten spelen een prominente rol bij de glucosestofwisseling. Zo is één van de effecten van het hormoon insuline dat het de glucoseopname door spiercellen stimuleert. Insuline bevordert dat de GIUT eiwitten van hun opslagplaats migreren naar de celmembraan om zodoende het in het bloed aanwezige glucose toegang te verlenen tot de cel. 
Ook melkzuur is een hydrofiele stof waarvoor de celmembraan een ondoordringbare barrière is. Ook voor melkzuur zijn speciale transporteiwitten in de membraan aangetroffen zodat opname door de hartspiercel mogelijk is. Er is echter geen translocatiemechanisme. Waarschijnlijk is daaraan geen behoefte.

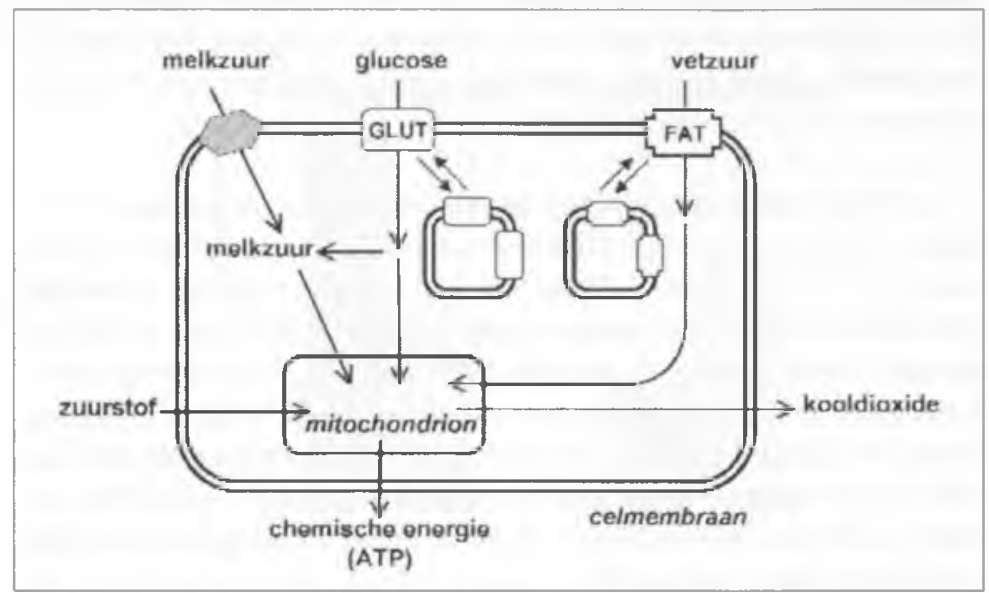

Fig. 5. Brandstofopname door de hartspiercel.

Tenslotte, maar zoals we gezien hebben zeker niet in de laatste plaats, beschouwen we vetzuren als brandstof voor het hart. Vetzuren zijn, zoals de naam al zegt, vetachtige stoffen die zich in de membraan prima thuis voelen en gemakkelijk bewegen tussen de fosfolipiden. De celmembraan vormt voor vetzuren waarschijnlijk geen ondoordringbare barrière. Daarmee leek het mechanisme van de vetzuuropname verklaard, hoewel het zou betekenen dat regulatie ervan niet mogelijk zou zijn.

In weerwil van dit 'verklaarde' fenomeen en tegen de heersende mening in - want soms is het goed om de stem van het hart te volgen zijn onderzoekers toch op zoek gegaan naar mogelijke, in de celmembraan aanwezige specifieke transporteiwitten voor vetzuren. In de afgelopen vijftien jaar is een drietal kandidaateiwitten ontdekt, ${ }^{\circ}$ waarvan ik er hier éen noem omdat deze prominent aanwezig is in de hartspiercel. Enkele jaren geleden hebben wij kunnen aantonen dat deze transporter, vetzuurtranslocase, vanuit het Engels kortweg FAT genoemd, werkelijk betrokken is bij de vetzuuropname door het hart. Daarna onderzochten 
we, in samenwerking met Arend Bonen in Guelph, Canada, of de transporter ook de opname reguleert, en zo ja, of dit plaatsvindt via een translocatiemechanisme zoals we dat kennen van de glucoseopname. Inderdaad konden we vaststellen dat FAT niet alleen aanwezig is in de membraan maar ook in cellulaire opslagplaatsen. Neemt de vetzuurbehoefte van de cel toe, dan migreert FAT vanuit deze opslagplaats naar de membraan om een hogere opnamesnelheid mogelijk te maken. En omgekeerd, neemt de vetzuurbehoefte weer af, dan keren de FAT eiwitten weer terug in de cel. (Fig. 5)."

Het mechanisme en de regulatie van de opname van glucose en vetzuren door de hartspiercel blijken dus opvallende parallellen te vertonen. Beide staan onder invloed van hormonen, zoals het al eerder genoemde insuline dat zowel de translocatie van GLUT als van FAT stimuleert. Ook bij fysieke inspanning, dat vraagt om een toename van de hartslag en dus meer energie, zien we een parallelle verhuizing van de twee transporters en, naar rato, een verhoogde opnamesnelheid van beide brandstoffen. Dit regelsysteem voor de brandstofopname functioneert naast het genoemde systeem waarbij het brandstofverbruik in de hartspiercel wordt aangepast.

Het zal duidelijk zijn dat vetzuren zich in een waterig milieu zoals het bloed niet thuis voelen en voor hun transport naar de weefsels afhankelijk zijn van transporteiwitten. In het bloed is dit het ruimschoots aanwezige eiwit albumine. Binnen de cel doet zich hetzelfde transportprobleem voor. De Amerikaanse gastroenteroloog Robert Ockner heeft in 1972 een klein eiwit ontdekt dat vetzuren bindt en wellicht fungeerde als de intracellulaire tegenhanger van het albumine." Dit eiwit wordt doorgaans met de Engelse term aangeduid als 'fatty acid-binding protein', afgekort FABP. Er bestaan verschillende types, zoals het hart-type FABP. Binnen mijn promotieonderzoek in Nijmegen, en later bij de capaciteitsgroep Fysiologie van deze universiteit heb ik de betekenis van dit FABP voor de hartspier onderzocht. Ter illustratie daarvan laat ik u de resultaten zien van een studie, destijds uitgevoerd door Frank Schaap, ${ }^{3}$ met muizen waarbij het gen dat codeert voor dit cardiale FABP door genetische manipulatie is verwijderd. Hartspiercellen geisoleerd uit deze zogenaamde 'knock-out' muizen blijken aanzienlijk minder vetzuren op te nemen dan cellen uit controlemuizen (Fig. 6). Belangrijk is dat de vetzuuropname niet onmogelijk is geworden; blijkbaar kan bij afwezigheid van FABP de functie ervan gedeeltelijk worden overgenomen 
door andere eiwitten. Opvallend is ook dat de verminderde vetzuuropname wordt gecompenseerd door een verhoogde glucoseopname. Dit toont de flexibiliteit van de energiestofwisseling van de hartspiercel, die daarmee en binnen zekere grenzen zowel intrinsieke als extrinsieke verstoringen het hoofd kan bieden.

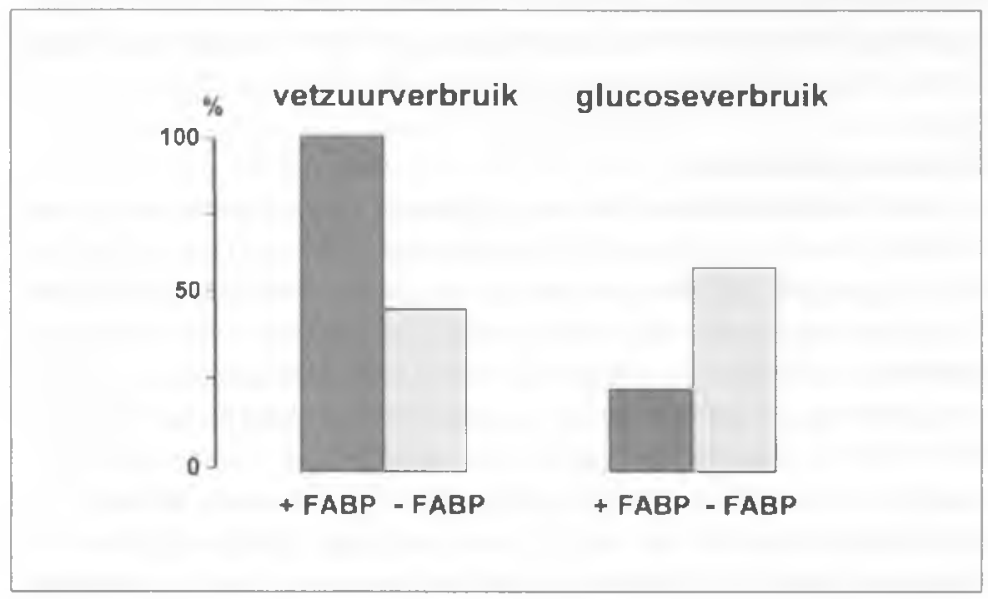

Fig. 6. FABP en energieproductie in de hartspiercel. 


\section{Dames en heren,}

In het voorafgaande heb ik u deelgenoot gemaakt van een stukje fundamenteel onderzoek op het terrein van de energiehuishouding van het hart waarbij een nieuw regelmechanisme voor de vetzuurstofwisseling is ontdekt, namelijk regulatie van de cellulaire vetzuuropname. Waarschijnlijk vraagt $u$ zich op dit moment af wat nu de relatie is tussen deze nieuwe kennis en de bestrijding van hart-en vaatziekten. In het navolgende wil ik daar graag op ingaan.

\section{Hart- en vaatziekten}

Hart en vaatziekten vormen nog steeds de belangrijkste oorzaak van ziekte en sterfte in de geïndustrialiseerde wereld (Fig. 7), ${ }^{14}$ maar hebben in de afgelopen decennia wel een geheel ander karakter gekregen. Het beeld van een fataal hartinfarct is vervangen door dat van hartfalen als chronische aandoening. Op geleide van door wetenschappelijk onderzoek verkregen inzichten zijn therapieën ontwikkeld die de sterfte van in het ziekenhuis opgenomen patiënten met een hartinfarct hebben verlaagd van zo'n 20\% in de jaren zestig tot zo'n $5 \%$ in 2004 . Dit komt o.a. door de trombolytische therapie die erop is gericht om bij patienten met een acuut infarct het bloedstolsel dat een kransvat afsluit op te lossen zodat de weefseldoorbloeding weer wordt hersteld en verder verlies van hartspierweefsel kan worden tegengegaan. Voor hetzelfde doel wordt tegenwoordig steeds vaker een dotterbehandeling toegepast. Het zal duidelijk zijn dat bij deze therapieen geldt dat hoe eerder ze worden ingezet hoe effectiever ze zullen zijn. Het begrip 'tijd = spier' heeft hier zijn intrede gedaan.

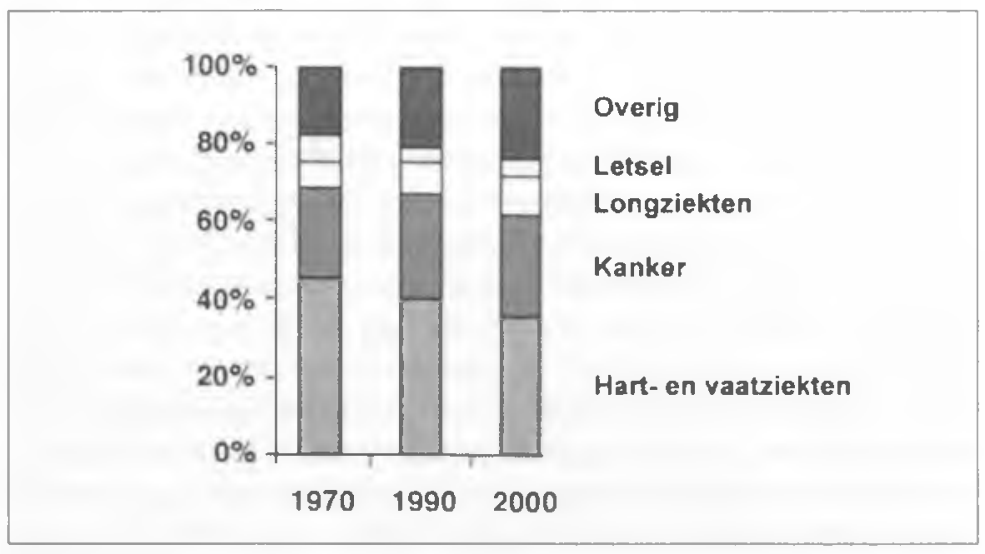

Fig. 7. Sterfte in Nederland naar doodsoorzaak. 
Met het beschikbaar komen van deze therapieen werd het steeds belangrijker zo snel mogelijk de juiste diagnose te kunnen stellen. Om onnodig risico te voorkomen worden alleen die patienten behandeld bij wie een opgetreden infarct is aangetoond. Op het gebied van de diagnostiek van hart- en vaatziekten zijn dan ook belangrijke vorderingen gemaakt. Onder andere betreft dit het meten van harteiwitten in de bloedbaan die daar normaal niet aanwezig zijn maar na het infarct door de beschadigde cellen daarin worden uitgestort. Omdat een electrocardiogram in ongeveer een kwart van de gevallen een opgetreden infarct niet registreert en de uitstort van harteiwitten in de bloedbaan in alle gevallen optreedt is deze bloedtest een standaard onderdeel van de diagnostiek en ook opgenomen in de officiële richtlijnen van de World Health Organisation. ${ }^{5} \mathrm{Nadeel}$ van de cardiale markeereiwitten is dat het enkele uren duurt voordat zij verhoogd in bloed aanwezig zijn. Men is daarom voortdurend op zoek naar die markeereiwitten die zo vroeg mogelijk na een infarct in de bloedbaan kunnen worden aangetoond.

Wij hebben aan dit onderzoek bijgedragen door te ontdekken dat het al eerder genoemde eiwit FABP relatief zeer snel na een infarct in de bloedbaan aanwezig is en momenteel het vroegst meetbare markeereiwit is. ${ }^{16}$ In Figuur 8 ziet $u$ de uitstortcurve van FABP vergeleken met die van de doorgaans gebruikte eiwitten creatine-kinase en troponine. Stel dat alle Nederlandse ziekenhuizen het standaard gebruikte creatine kinase vandaag zouden vervangen door FABP, wat is dan de winst voor

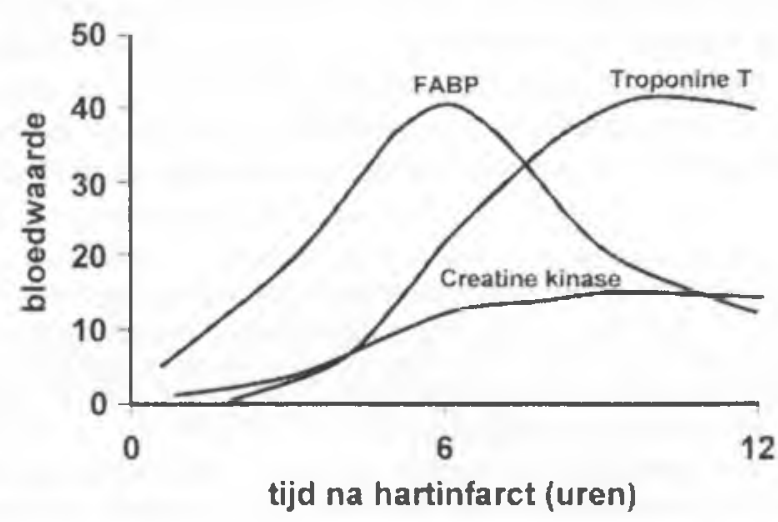

Fig. 8. Markeereiwitten in bloed na een acuut hartinfarct. 
patiënten die zich met pijn op de borst melden bij de Eerste Hart Hulp, rekening houdend met het feit dat markeereiwitten in een kwart van de gevallen daarvoor bepalend zijn? Het valt te berekenen* dat per jaar in Nederland bij zo'n 3.000 patiënten de trombolytische therapie dan enkele uren eerder kan aanvangen. Uit omvangrijk onderzoek (met in totaal 30.000 patiënten) weten we dat bij vroege ten opzichte van late behandeling de sterftekans flink afneemt. ${ }^{1920}$ Gezien de grote patiëntenaantallen is het vroeger beginnen met therapie dus niet onbelangrijk. Bovendien zouden, bij het gebruik van FABP, patiënten die geen infarct blijken te hebben niet langer ter observatie in het ziekenhuis hoeven blijven en sneller naar huis kunnen. Dat werkt kostenbesparend.

Uit zeer recent onderzoek blijkt FABP, in vergelijking met troponine, ook superieur voor het aantonen van minimale hartschade bij patiënten met chronisch hartfalen. ${ }^{18}$ Bij gebruik van FABP zouden naar schatting." per jaar in Nederland ca. 5.000 patiënten worden geïdentificeerd die een andere behandeling zouden moeten krijgen. Voldoende redenen, lijkt mij, om deze onderzoeken ook in de klinische fase voort te zetten.

Binnen het wetenschappelijk onderzoek op het gebied van hart- en vaatziekten heeft traditiegetrouw de bestudering van risicofactoren voorop gestaan. Dit zijn met name hoge bloeddruk en atherosclerose (aderverkalking). Meestal werden deze risicofactoren afzonderlijk onderzocht, en niet zonder succes. Alombekend is het feit dat verlaging van het cholesterolgehalte van het bloed, hetzij door aanpassing van de voeding hetzij door medicamenteus ingrijpen, leidt tot minder atherosclerose en daarmee tot een verminderd risico. Verder is gebleken dat bepaalde typen vetzuren, namelijk de meervoudig onverzadigde (omega-3) vetzuren die voorkomen in vis, een gunstig effect hebben op diverse risicofactoren voor hart- en vaatziekten." Door de verkregen inzichten is ook preventie een belangrijk onderwerp geworden. Aangetoond is dat een gezonde leefstijl, dat wil zeggen niet roken, vol-

- In Nederland worden per jaar ca. 25.000 patiënten in het ziekenhuis opgenomen met een acuut hartinfarct." Voor een kwart van deze patiënten (co. 6.000) zijn markeereiwitten essentieel geweest bij het stellen van de diagnose. Omdat ongeveer de helft van deze patiënten zich binnen drie uur na begin van klachten meldt bij het ziekenhuis," hebben ca. 3.000 patiënten baat bij een snellere diagnose.

- Het aantal ziekenhuisopnames van patiënten met chronisch hartfalen bedroagt $c 0.20 .000$ per jaar." Bij ongeveer een kwart van deze patiënten (ca. 5.000 patiënten) is minimale hartschade aantoonbaar met FABP maar niet met troponine." 
doende beweging en een verantwoorde voeding, van groot belang zijn bij het terugdringen van hart- en vaatziekten.

Door een betere preventie en een betere behandeling overleven steeds meer patiënten een hartinfarct. Dit verklaart het groeiend aantal mensen met een hart waarvan de pompfunctie tekortschiet. Organen en weefsels krijgen hierdoor te weinig zuurstofrijk bloed. Afvalstoffen en vocht worden minder goed afgevoerd. Er is sprake van chronisch hartfalen. Hartfalen kan ook het gevolg zijn van een hoge bloeddruk of ritmestoornissen.

\section{Integrale aanpak hart- en vaatziekten}

De nieuw verworven kennis omtrent elk van de genoemde risicofactoren heeft ook geleid tot het besef van verwevenheid en interactie ertussen. Anders gezegd, men komt steeds meer tot het inzicht dat het denken in afzonderlijke risicofactoren vervangen moet worden door denken in samenhangende risicofactoren.

De laatste tien jaar is naar voren gebracht dat er wellicht een gemeenschappelijke factor verantwoordelijk is voor de verstoring van het fysiologisch evenwicht, de homeostase, leidend tot hart- en vaatziekten. Genoemd zijn o.a. veranderingen in de weefseldoorbloeding en het optreden van een ontsteking. Een verstoring in de energiehuishouding zou ook een gemeenschappelijke factor kunnen zijn. Als een cel zijn energieproductie niet op orde heeft, zal de beschikbare chemische energie steeds selectiever moeten worden ingezet. Dit kan leiden tot verval van functie.

Dat deze laatste mogelijkheid serieuze aandacht verdient, wil ik hier nader toelichten.

Naast hart-en vaatziekten vormen ook vetzucht (obesitas) en suikerziekte (met name ouderdomsdiabetes) een steeds grotere bedreiging voor de volksgezondheid in Westerse landen (Fig. 9)." Steeds meer tekent zich een verband af tussen deze drie. Vetzucht is een risicofactor voor het krijgen van diabetes, en diabetes vergroot de kans op hart- en vaatziekten. Diabetici lopen niet alleen meer risico doordat de vaateigenschappen veranderen, maar overlijden na een infarct ook eerder dan niet-diabetici. Bij diabetes verandert er dus ook iets in de hartspier zelf. Ernst en omvang van diabetes worden nog altijd zwaar onderschat. ${ }^{23}$ 


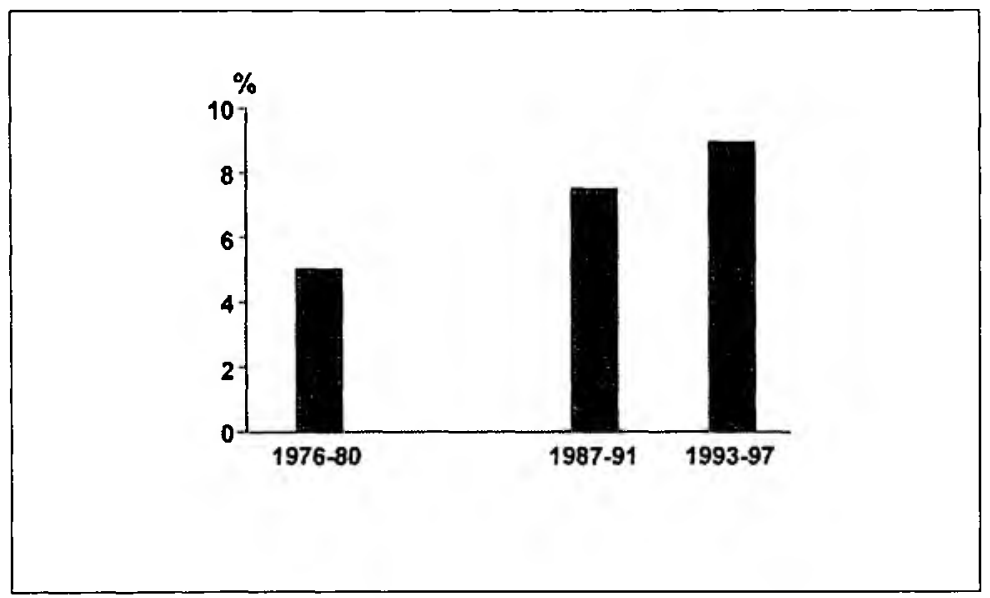

Fig. 9. Percentage volwassenen met vetzucht (obesitas) in Nederland.

\section{Hartziekten en de voedingsstoffenbalans}

Vetzucht en diabetes zijn stofwisselingsziekten waarbij veranderingen in de glucose en vethuishouding centraal staan. Het ligt dus voor de hand om te bestuderen hoe het hart bij deze ziektes zijn energievoorziening waarborgt, en in het bijzonder of het ontdekte regelmechanisme van de vetzuuropname hierbij een rol speelt.

Bij diabetes is het hart minder goed in staat om vanuit het bloed glucose op te nemen, en zal daarom overschakelen op de verbranding van andere stoffen, met name vetzuren. Inderdaad blijkt in het diabete hart het aandeel van vetzuren in de energieproductie te zijn toegenomen van $60 \%$ naar meer dan $90 \%$. In onderzoek bij proefdieren hebben wij vastgesteld dat deze aanpassing in brandstofvoorkeur gepaard gaat met een herverdeling van het in de cel aanwezige FAT. De totale hoeveelheid FAT blijft gelijk, maar er vindt een verschuiving plaats. Een deel van het opgeslagen FAT verhuist naar de celmembraan. Deze herverdeling kan de grotere vetzuuropname van het diabete hart verklaren. Om na te gaan of deze veranderingen ook bij de diabete patiënt van toepassing zijn, hebben we skeletspierbiopten onderzocht van personen in verschillende stadia van ontwikkeling van diabetes (Fig. 10). Het blijkt dat de ernst van deze ziekte - op de verticale as weergegeven - samenhangt met de hoeveelheid op de membraan aanwezig FAT. ${ }^{24}$ Dit suggereert dat dit eiwit een prominente rol speelt bij de veranderingen in de diabete spier. Anderszijds is bekend dat de ontwikkeling van diabetes ook 
gepaard gaat met een toename van de vetopslag in hart en skeletspieren. In onze patiëntenstudie hebben we dat voor de skeletspier ook waargenomen. Op grond van deze en andere studies concluderen wij dat het diabete hart uit balans is: er worden meer vetzuren opgenomen dan voor energieproductie nodig; het teveel wordt in de cel opgeslagen. Er zijn aanwijzingen dat deze vetopslag de pompfunctie van het hart nadelig beïnvloedt en ook de glucoseopname verder terugdringt. Er ontstaat dan een vicieuze cirkel waarbij de diabetes steeds meer verergert. Wij menen dan ook dat bij diabetesonderzoek niet zozeer de glucosehuishouding maar juist ook de vetzuurhuishouding centraal zou moeten staan.

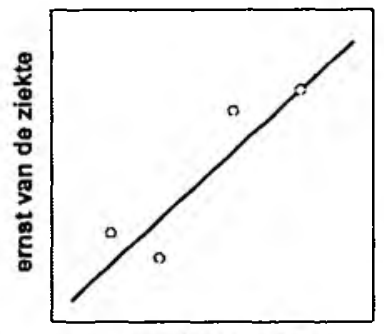

membraan FAT

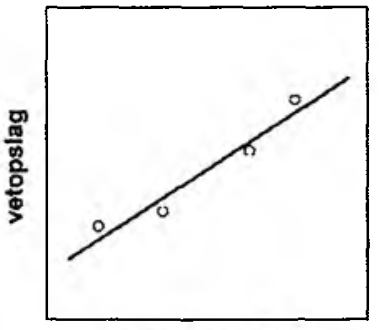

membraan FAT

Fig. 10. Verband tussen (de ernst van) diabetes en de hoeveelheid FAT eiwit in de membraan van skeletspiercellen.

Bij diabetes zagen we dat het aandeel van vetzuren aan de energieproductie is toegenomen. Komt het omgekeerde ook voor, dus dat het aandeel van glucose toeneemt? Dit is zeker het geval. Namelijk, bij het al genoemde falende hart zien we een verschuiving van de voedingsstoffenbalans in de richting van glucose. Belangrijk is natuurlijk of deze verschuiving oorzaak of gevolg is van het minder goed functioneren van het falende hart. Dit weten we nog niet, maar het verband is heel sterk. Want als een gezond hart wordt gedwongen over te schakelen op glucoseverbranding, bijvoorbeeld door een (farmacologische) remming van het vetzuurverbruik, leidt dit op den duur tot hartfalen. ${ }^{25}$ 


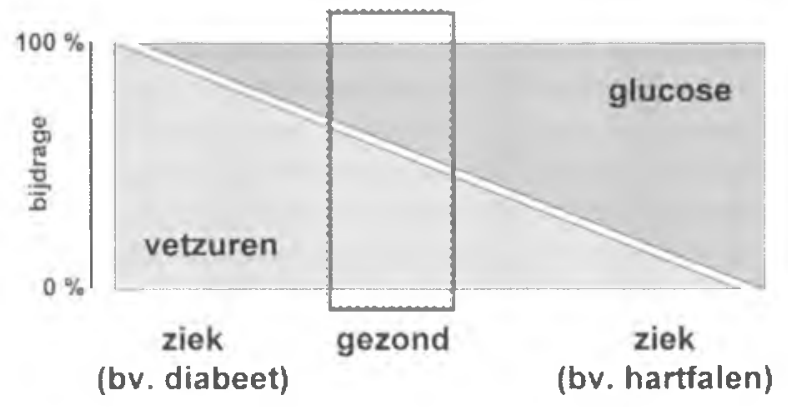

Fig. 11. De brandstoffenbalans van het hart. Een nieuw concept.

Ons hier gepresenteerde, volledig nieuwe concept is dus dat een optimale hartfunctie nauw samenhangt met een bepaalde ingestelde waarde van de brandstoffenbalans (Fig, 11). Verschuift deze balans te ver weg van de ingestelde waarde dan heeft dat nadelige gevolgen voor de pompfunctie. Bij ouderdomsdiabetes is de balans doorgeslagen richting vetzuren, terwijl bij chronisch hartfalen de balans is doorgeslagen richting glucose. In beide gevallen vermindert de pompfunctie. Anderszijds kan een verschoven balans gezien worden als een aanwijzing dat de hartfunctie is a angedaan en dus van nut zijn bij het stellen van een diagnose. Het is aannemelijk dat herstel van de brandstoffenbalans tot binnen een bepaalde bandbreedte zal bijdragen aan een verbetering van de pompfunctie van het hart. Omdat deze balans voornamelijk wordt bepaald door de aanwezigheid van glucose- en vetzuurtransporters in de celmembraan ligt hier, en in de daarbij betrokken translocatiemechanismen, een aangrijpingspunt voor therapie.

Naast toepassing bij chronische ziekten, verwacht ik dat een dergelijk ingrijpen in de brandstoffenbalans ook in acute situaties zinvol kan zijn Bij een hartinfarct is er onvoldoende a anvoer van zuurstof naar het hart. Vetzuren kunnen dan niet worden verbrand, hopen zich op, en beschadigen, door hun zeepachtige werking, de cellen. Glucose is dan een betere voedingsstof want ook zonder zuurstof kan hieruit energie worden vrijgemaakt. In 1962 stelde Sodi-Pallares al voor ter behandeling van een infarct het hart te doorspoelen met een glucosebevattende oplossing. ${ }^{26}$ 
Daarmee is hij in feite de uitvinder van de 'metabole therapie'. Deze therapie is al gauw in vergetelheid geraakt, maar zoals wel vaker gebeurt, zien we nu, veertig jaar later, een opnieuw ontdekken ervan, getuige recent werk van een Zwolse groep cardiologen. ${ }^{27}$ Zelfs dringt het besef door dat metabolisme in algemene zin een ondergewaardeerd aangrijpingspunt is voor behandeling van het zieke hart. ${ }^{28}$

\section{Onderzoeksplannen}

In de komende jaren willen wij in Maastricht de glucose-vetzuur brandstoffenbalans aan nader onderzoek onderwerpen. Door meer inzicht te verwerven in de factoren die deze balans bepalen verwachten we ook mogelijkheden te vinden om te kunnen ingrijpen. Op termijn denken we aan gerichte aanpassing van de voedingssamenstelling of aan medicamenteuze behandeling.

In de aanpak van biomedisch onderzoek is de laatste jaren, en zeker sinds de jaren van Richard Bing, veel veranderd. Er zijn vele nieuwe technieken beschikbaar gekomen. Gezien de beperkte tijd wil ik hier volstaan met het noemen van de voor mijn onderzoek relevante techniek waarbij de opname van glucose en vetzuren door het hart rechtstreeks kan worden zichtbaar gemaakt. Door gebruik van gemerkte voedingsstoffen en geavanceerde detectieapparatuur (bijvoorbeeld positron emissie tomografie) kan een verandering in vetzuuropname worden gezien, en kan ook worden achterhaald welke delen van het hart niet meer metabool actief zijn. ${ }^{29}$ Binnenkort zal deze techniek worden verfijnd en ook toepasbaar zijn in onderzoek met kleine proefdieren.

Met name op het gebied van de moleculaire genetica verlopen de ontwikkelingen stormachtig. Muismodellen waarin bepaalde genen al dan niet weefselspecifiek zijn verwijderd of bijgeplaatst, de transgene muizen, hebben hun waarde in het onderzoek bewezen. Ik noemde hier al ons onderzoek aan een muis die het gen voor het FABP eiwit mist. De - nu ook in Maastricht beschikbare - expertise reikt inmiddels zo ver dat het mogelijk is muizen te genereren waarin bepaalde genen op elk gewenst tijdstip kunnen worden aan- of uitgeschakeld door toediening van specifieke stoffen aan de voeding.

Het grote voordeel van deze onderzoeksbenadering is dat rechtstreeks een verband kan worden gelegd tussen de aan- of afwezigheid van een gen, dus het genotype, en het functioneren van het intacte 
organisme, dus het fenotype. We moeten ons wel goed realiseren dat deze benadering ook zijn beperkingen kent. Omdat op alle niveaus fysiologische regelmechanismen actief zijn, gericht op de evenwichtige instandhouding van het individu, is interpretatie van de onderzoeksresultaten niet gemakkelijk en niet altijd eenduidig. Een eenvoudig voorbeeld is dat het verwijderen van een gen kan worden gecompenseerd doordat een ander gen actief wordt en de betreffende fysiologische functie door een ander eiwit wordt overgenomen. In dat geval blijft de rol van het verwijderde gen voor de onderzoeker verborgen.

Dat een dergelijke geïntegreerde aanpak van onderzoek complex kan zijn wil ik illustreren aan de hand van het eiwit FAT. Tussen het gen, het bijbehorende eiwit en de bijbehorende fysiologische functie in het intacte organisme zijn vele factoren actief, die ieder op hun niveau weer worden beïnvloed door tal van regelmechanismen in de cel. Signaalstoffen, zoals hormonen, bepalen of het betreffende gen tot expressie komt. Deze aansturing is complex; er zijn wel tientallen eiwitten bij betrokken. Daarna moet het eiwit correct worden gevouwen en worden er andere stoffen aan gekoppeld zoals suikergroepen, fosforgroepen en vetachtige verbindingen die straks zorgen dat het FAT in de celmembraan een plaats vindt. Voor het transport van FAT in de cel zijn weer vele andere eiwitten nodig. De eindbestemming is in een specifiek domein van het membraan, waar het eiwit pas actief is als het in interactie kan zijn met andere eiwitten, met cholesterol en met bepaalde fosfolipiden. Een interessant detail is dat vetzuren niet alleen brandstof zijn maar ook bijvoorbeeld de genexpressie beïnvloeden.

Dit besef van een complexe regulatie is niet nieuw maar dringt de laatste jaren wel sterker door in de biomedische onderzoekswereld. Zagen we in de tweede helft van de vorige eeuw het steeds verder opdelen van de disciplines in steeds weer nieuwe subspecialisaties, de laatste jaren is er weer een tendens naar integratie van de verschillende deelgebieden onder de noemer 'integratie van de levenswetenschappen van molecuul tot individu'. Dit is een goede ontwikkeling. Daarbij passend maakt een reductionistische onderzoeksbenadering weer plaats voor een integratieve benadering.

De uitdaging binnen het onderzoek is om de beschikbare en zich snel uitbreidende expertises optimaal te benutten. Samenwerking tussen onderzoekers met een genetische en met een fysiologische achtergrond 
zal daarbij een krachtige combinatie zijn. Het is ook daarom dat ik meen dat het onderbrengen van mijn leerstoel binnen de sectie Moleculaire Genetica veel perspectief biedt.

\section{Organisatie en werkomgeving}

We hebben zojuist gezien waar de hartspier zijn energie vandaan haalt om voortdurend actief te zijn, en, als de vraag zich voordoet, tot een uiterste inspanning in staat is. Maar waar haalt de onderzoeker zijn energie vandaan? Deskundigheid en creativiteit alleen zijn niet voldoende. Ook nodig zijn een inspirerende en faciliterende werkomgeving en voldoende financiële middelen. Net zoals we dat gezien hebben voor de brandstoffen voor het hart, geldt ook hier dat beide zaken in een zekere balans beschikbaar moeten zijn (Fig. 12). Dit brengt mij bij de organisatie van het onderzoek.

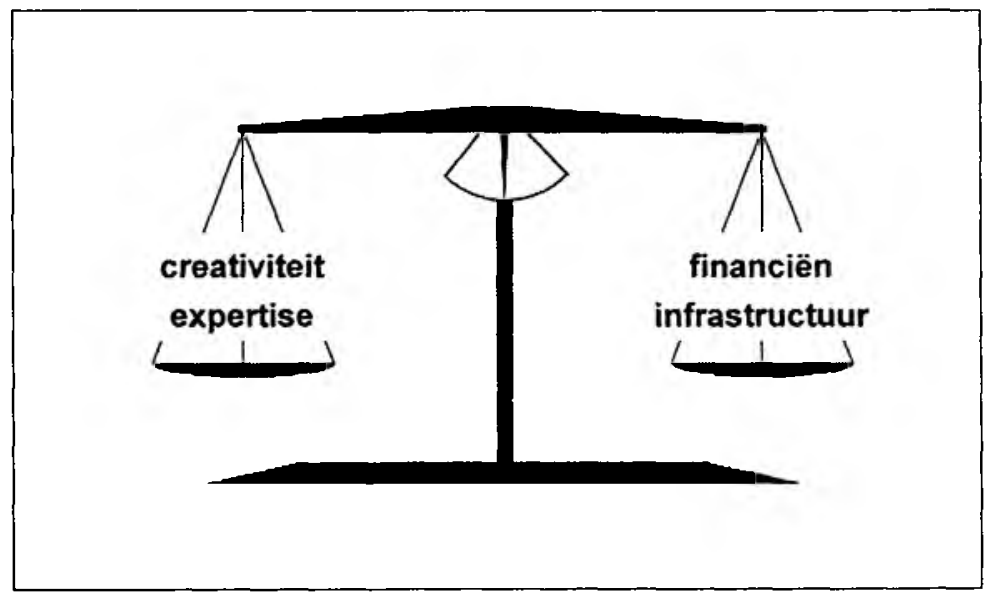

Fig. 12. Benodigdheden voor wetenschappelijk onderzoek.

In de afgelopen vijftien jaar is vrijwel al het universitaire onderzoek ondergebracht in onderzoeksscholen en -instituten. Deze ontwikkeling past bij de bovengenoemde multidisciplinaire, integrale aanpak van onderzoek en bij de gewenste focussering op specifieke aandachtsgebieden. Bundeling van expertises zal leiden tot onderzoek van hoge kwaliteit. Het is algemeen bekend dat de belangrijkste nieuwe ontwikkelingen in de wetenschap zich voordoen op het snijvlak van disciplines. 
De organisatie van het onderzoek in instituten kent ook een potentieel risico. Door de drang tot herkenbaarheid worden rondom de instituten virtuele muren opgetrokken die samenwerking tussen de instituten onderling kunnen belemmeren. Naar mijn mening moeten er ook stenen bewaard worden voor het bouwen van bruggen tussen de instituten op die plaatsen waar in synergie samengewerkt kan worden.

Het onderzoeksinstituut CARIM is in 1988 opgericht en heeft inmiddels nationaal en internationaal een uitstekende naam verworven. ${ }^{30}$ Op dit stevige fundament heeft CARIM nu de ambitie geformuleerd het instituut zodanig uit te bouwen dat het tot de Europese top gaat behoren. Dit is een prijzenswaardig initiatief maar vereist een optimale inzet van personeel en middelen. Hiervoor is een krachtige interne organisatie nodig.

Ter versterking daarvan zou CARIM - maar dat geldt ook ook andere instituten - mijns insziens moeten overgaan tot het instellen van een onafhankelijk forum of een commissie die bestaat uit een brede vertegenwoordiging van medewerkers, en die tot taak heeft gevraagd en ongevraagd te adviseren over voor het instituut belangrijke aangelegenheden. De instelling van een dergelijke commissie heeft een aantal voordelen:

1. Het vergroot de mobilisatie van kennis en expertise die binnen het instituut beschikbaar is en daarmee de mogelijkheid om voorkomende kansen optimaal te benutten;

2. Het draagt bij aan het creëren van draagvlak voor te nemen maatregelen en te maken keuzes;

3. Het past in een beleid om medewerkers te scholen in management van het wetenschappelijk onderzoek.

Op grond van mijn ervaring met de Opleidingscommissie Geneeskunde, die deze taak - overigens op wettelijke basis - vervult binnen het Onderwijsinstituut," verwacht ik dat de instelling van zo'n commissie zeker zinvol zal zijn en zal bijdragen aan de langetermijndoelstellingen van onderzoeksinstituten.

In dit verband is ook veel te verwachten van de trainingen die momenteel door de Universiteit Maastricht aan haar medewerkers worden aangeboden en die de verdere uitbouw van managenement- en leiderschapsvaardigheden tot doel hebben. Als onderdeel van het Strategisch Programma is een uniek, op de Universiteit Maastricht toe- 
gesneden programma van trainingen ontwikkeld dat recht doet aan het belang van de medewerker als sleutel tot het succes van deze instelling. ${ }^{32}$ Daarmee krijgt het begrip PGO, dat oorspronkelijk staat voor 'probleemgestuurd onderwijs' en is uitgegroeid tot het handelsmerk van deze universiteit, een betekenis erbij: PGO staat dan ook voor 'personeelsgerichte organisatie.'

Financiële middelen voor onderzoek zijn in toenemende mate een zorg voor de onderzoeker. De basisfinanciering wordt steeds verder beperkt. Het verkrijgen van externe middelen is van wens tot noodzaak gegroeid. Subsidieverstrekkers willen het risico van geïnvesteerd geld tot een minimum beperken en laten bij hun beoordelingen de haalbaarheid van het onderzoeksvoorstel en de toepasbaarheid van de te verwachten resultaten steeds meer de boventoon voeren. Ook is de kans op toekenning van een ingediend projectvoorstel afgenomen tot soms minder dan $20 \%$. Is een onderzoeker niet bezig het ene project te schrijven dan is hij bezig het andere project te beoordelen. Deze taken leggen een te groot beslag op de tijdsbesteding van de onderzoeker; de balans is hier doorgeslagen. Kortom, de broodnodige ruimte voor nieuwsgierigheidsgedreven onderzoek staat onder druk.

Gelukkig is er een tegenstroming. Er komen steeds meer persoonsgerichte programma's, waarbinnen meer ruimte is voor eigen invulling en tussentijdse bijstelling van onderzoeksplannen. Investeren dus in personen in plaats van in plannen. De Nederlandse Hartstichting, financier van ongeveer de helft van al het hart- en vaatziektenonderzoek in Nederland, is éen van de eersten geweest die het belang hiervan heeft ingezien. In 1978 startte zij het persoonsgerichte Dekker programma, genoemd naar haar eerste Medisch Directeur Dr. Bart Dekker.33 Onderzoekers krijgen ruimte voor ontplooiing en binden zich aan harten vaatziektenonderzoek. Uit eigen ervaring weet ik dat dit een belangrijke vliegwielfunctie heeft. Het Dekkerprogramma is zeer succesvol, getuige het feit dat vrijwel alle laureaten nog steeds actief zijn in het onderzoek.

\section{Onderwijs}

Het Maastrichtse onderwijssysteem wordt gekenmerkt door een sterk multidisciplinair karakter. Daardoor krijgt het geven van onderwijs een duidelijke meerwaarde voor de docent. Immers, interactie met collegae uit andere disciplines verruimt de blik, en dat is niet alleen goed 
voor de medewerker in zijn of haar rol als docent, maar ook in zijn of haar rol als onderzoeker. Ook op andere vlakken is kruisbestuiving tussen onderwijs en onderzoek aan de orde. Zo zijn de vaardigheden die docenten opdoen in het onderwijs aan studenten ook van nut bij het verzorgen van onderwijs aan promovendi, en omgekeerd.

Omdat deze universiteit sterk is in onderwijsvernieuwing, liggen hier unieke mogelijkheden. Binnen de studie geneeskunde, met name de nog te starten vierjarige opleiding, is ingezet op verdere individualisering van het onderwijs, waarbij het doel is studenten een leeromgeving aan te bieden en hen te begeleiden opdat zij vakbekwaam worden en voorbereid zijn op een beroepsleven waarin doorlopend leren een belangrijk kenmerk is. Deze benadering leent zich bij uitstek ook voor de opleiding van wetenschappelijk onderzoekers. Het voorstel om binnen de Faculteit der Ceneeskunde een masteropleiding Cardiovasculaire Biologie en Geneeskunde te starten past hier uitstekend bij. Het is een fraai voorbeeld van hoe de expertises van twee instituten, in dit geval CARIM en het Onderwijsinstituut, zinvol bij elkaar gebracht kunnen worden.

Voor elke onderzoeker is er dus alle reden om onderwijs een warm hart toe te dragen. Het is een plezierige taak en geeft een verrijking van inzichten en vaardigheden. Onderwijs moeten we zien als een gezamenlijke opdracht. Het zou goed zijn als iedere medewerker, van postdoc tot directeur en decaan, actief bij het onderwijs is betrokken door per jaar tenminste één onderwijsrol te vervullen waarbij er direct contact is met studenten. 


\section{Dankwoord}

Aan het einde van deze rede past een woord van dank. Graag wil ik al diegenen bedanken die hebben bijgedragen aan mijn ontwikkeling als persoon en als wetenschapper.

In tegenstelling tot hetgeen gebruikelijk is wil ik allereerst mijn ouders bedanken voor hun voortdurende steun en stimulans. Ik ben verheugd dat mijn moeder hier vandaag aanwezig is.

In het bijzonder noem ik mijn veel te vroeg overleden vader, die enkele weken geleden zijn tachtigste verjaardag gevierd zou hebben. Zijn warmte en levenswijsheid zijn voor mij nog dagelijks een bron van inspiratie.

De Nederlandse Hartstichting dank ik voor het instellen van deze leerstoel. Het is een bijzondere eer voor mij om als Hartstichtingshoogleraar door het leven te mogen gaan. Al eerder heb ik in het kader van het genoemde Dekker-programma mogen profiteren van een aanstelling als Established Investigator. Ik verheug me erop in de komende jaren een verdere bijdrage te leveren aan het verwezenlijken van de doelstellingen van de Nederlandse Hartstichting.

Het College van Bestuur van deze universiteit, het bestuur van de Faculteit der Geneeskunde en het College van Toezicht van deze leerstoel, met professor Harry Hillen als voorzitter, dank ik voor het in mij gestelde vertrouwen.

Professor Veerkamp, beste Jacques. Tijdens mijn promotieperiode in jouw laboratorium in Nijmegen is de solide basis gelegd voor mijn wetenschappelijke carrière. Ik kijk daar nog vaak met voldoening op terug.

Professor Katan, beste Martijn. Hoewel ik nog geen drie jaar als postdoc aan het Wageningse voedingsonderzoek heb meegewerkt, heb ik in deze periode op vele vlakken veel geleerd. Aan je ideeën en werkwijzen denk ik nog regelmatig terug.

De professoren Reneman en van der Vusse, beste Rob en Ger. In 1986 hebben jullie mij naar Maastricht gehaald omdat jullie geloofden in de 
concepten die ik in een eerdere lezing had uitgelegd en me de kans wilde geven deze verder te gaan uitzoeken en me te bekwamen in de fysiologie. Ik ben jullie dankbaar voor deze visie.

Professor Struijker Boudier, beste Harry. Toen je directeur van CARIM werd nam je de ontwikkeling van medewerkers serieus ter hand. Jouw betrokkenheid, oprechtheid en wetenschappelijke visie bewonder ik zeer. Ik dank je ook heel hartelijk voor je niet aflatende persoonlijke steun.

De professoren Geraedts en Hofker, beste Joep en Marten. Jullie beiden dank ik voor de geschapen mogelijkheid mijn onderzoek op de afdeling Genetica en Celbiologie voort te zetten. Marten, jij verstaat de kunst een inspirerend leider te zijn en ook ruimte te geven voor persoonlijke ontplooiing. Ik verheug me op een verdergaande samenwerking met jou en met de andere leden van de sectie Moleculaire Genetica.

Professor Hermens, beste Wim. Tussen de termen 'moleculaire fysica' en 'moleculaire fysiologie' zijn driekwart van de letters identiek. Toch zit er tussen jouw en mijn vakgebied een wereld van verschil. Jouw wijze en filosofische lessen in de fysica blijven me altijd bij. De diagnostiek van hartspierschade met het markeereiwit FABP bracht ons bij elkaar. Binnen deze samenwerking groeide ook een bijzondere persoonlijke band en ben je op cruciale momenten een onmisbaar klankbord voor mij.

Professor Bonen, University of Guelph, Canada. Dear Arend, I am delighted that you are with us here today. Our close collaboration, intensified by Joost's stay in your laboratory has been very stimulating for me in both scientific and personal senses. The so-called 'blue room' discussions have become a household word even though the three of us now meet at a different location. I feel priviledged being able to continue our journey exploring the country of muscle metabolism together with you.

Professor Spener, Universität Münster, Deutschland. Lieber Fritz, seit genau zwanzig Jahre arbeiten wir jetzt zusammen. Am Anfang in der FABP Forschung, im Laufe der Zeit immer mehr als Botschafter der Lipidwissenschaft. Ich unterstütze deine Meinung dass die Lipidforschung ('Lipidomics') mehr Beachtung verdient, ${ }^{34,35}$ und werde mich dafür weiter einsetzen diesen Traum Realität werden zu lassen. 
En dan de leden van mijn onderzoeksgroep die net zo belangrijk zijn als de bemanning van een schip. Dr. Luiken, beste Joost, jij bent tien jaar geleden aan boord gekomen en je hebt je ontwikkeld tot een belangrijk, creatief en gewaardeerd bemanningslid. Ceen hypothese is zo wild of $\mathrm{jij}$ duikelt wel een stofje op dat kan helpen bij het toetsen ervan. Lange tijd dreigde je buiten boord te vallen, maar door vastberadenheid en jouw inzet zijn we door de woelige wateren heen kunnen komen. Samen met Will, Maurice, Daniëlle, Roy, Debby en Susan is de bemanning op sterkte, en met Masja en Kees onder de enthousiaste leiding van Dick van der Horst op een langszijvarende Utrechtse boot kunnen we in vertrouwen op weg.

De collega's binnen het Onderwijsinstituut dank ik voor de voor mij inspirerende samenwerking en de persoonlijke contacten. Albert, Ineke, Bert en Marcel: jullie wil ik met name noemen, maar zonder tekort te doen aan alle anderen binnen het onderwijsveld en de Opleidingscommissie, inclusief de plezierige contacten en samenwerking met studenten geneeskunde.

Jodil Willems bedank ik voor zijn computerhulp bij deze presentatie.

Familie en vrienden bedank ik voor het meeleven in minder spannende en spannende tijden.

Tenslotte keer ik weer terug naar daar waar het allemaal begon, de thuisbasis. Het ouderlijk gezin heeft plaatsgemaakt voor een eigen gezin.

Lieve Marie-Adele, als er één is die ertoe heeft bijgedragen dat ik hier nu sta ben jij het. Dit tinnen beeldje, van voor jou bekende makelij, wil deze bijzondere rol symboliseren en herinnert ons aan de overdrachtelijke betekenis van de titel van deze rede. Jij hebt het hart op de juiste plaats zoals hier zo fraai uitgebeeld. Als de balans tussen mijn aandacht voor het werk en aandacht voor thuis weer eens in de eerste richting verschoof, hield jij mij deze spiegel terecht voor, maar kwam dan vaak zelf in een dilemma terecht. Door je ongekend grote inlevingsvermogen in anderen en inhoudelijke kennis van de geneeskunde toonde je veel begrip. Dit maakte je rol bij het herstel van de balans niet eenvoudig. Hopelijk kunnen we dit belangrijke evenwicht in de toekomst beter bewaken. Immers, een hart voor balans houdt het hart in balans. 
Eline en Barbara, onze twee dromen van dochters. Als jullie iets meemaken dat je geweldig vindt roepen jullie altijd "Dat is pas vet!"Vandaag heb ik jullie uitgelegd wat $i k$ onder vet versta, waarom ik er zo enthousiast over ben, en hoe dit vet centraal staat in ons onderzoek. Je zult dan ook begrijpen dat ik nu roep, samen met jullie: Vet, dat is pas vet!

Dank voor uw aandacht.

ik heb gezegd. 


\section{Literatuur}

1. Bing RJ, Siegel A, Ungar I, Gilbert M. Metabolism of the human heart. II. Studies on fat, ketone and amino acid metabolism. Am J Med 16: 504-515. 1954.

2. Hurst JW. Richard John Bing, MD: A conversation with John Willis Hurst, MD. Am J Cardiol 86: 72-79, 2000.

3. Evans CL. The effect of glucose on the gaseous metabolism of the isolated mammalian heart. J Physiol 47:407-414, 1914.

4. Visscher MB, Mulder AG. Carbohydrate metabolism of the heart. Am J Physiol 94: $630-639,1930$.

5. Bing RJ. The metabolism of the heart. Harvey Lect 50: 27-70, 1954-1955.

6. Shipp JC. Opie LH, Challoner D. Fatty acid and glucose metabolism in the perfused heart. Nature 189: 1018, 1961.

7. Randle PJ, Garland PB, Hales CN, Newsholme EA. The glucose fatty-acid cycle. Lancet I: $785-789,1963$.

8. Frayn KN. The glucose/fatty acid cycle 1963-2003: A tribute to sir Philip Randle. Biochem Soc Trans 31: 1115-1119, 2003.

9. Mueckler M. Facilitative glucose transporters. Eur J Biochem 219:713-725, 1994.

10. Glatz JFC, Storch J. Unravelling the significance of cellular fatty acid-binding proteins. Curr Opin Lipidol 12: 267-274, 2001.

11. Glatz JFC, Bonen A, Luiken JJFP. Exercise and insulin increase muscle fatty acid uptake by recruiting putative fatty acid transporters to the sarcolemma. Curr Opin Clin Nutr Metab Care 5: 365-370, 2002.

12. Ockner RK, Manning JA, Poppenhausen RB, Ho WK. A binding protein for fatty acids in cytosol of intestinal mucosa, liver, myocardium and other tissues. Science 177: 56-58, 1972.

13. Schaap FG, Binas B, Danneberg H, Van der Vusse GJ, Glatz JFC. Impaired longchain fatty acid utilization by cardiac myocytes isolated from mice lacking the heart-type fatty acid-binding protein gene. Circ Res 85: 329-337, 1999.

14. Koek HL, Van Leest LATM, Verschuren WMM, Bots ML. Hart- en vaatziekten in Nederland 2004, cijfers over leefstijl- en risicofactoren, ziekte en sterfte. Den Haag: Nederlandse Hartstichting, 2004, pp. 7-17. 
15. Alpert JS, Thygesen K, Antman E, Bassand JP. Myocardial infarction redefined: A consensus document of The Joint European Society of Cardiology/ American College of Cardiology Committee for the redefinition of myocardial infarction. J Am Coll Cardiol 36: 959-969, 2000.

16. Glatz JFC, Van der Voort D, Hermens WT. Fatty acid-binding protein as the earliest available plasma marker of acute myocardial injury. J Clin Ligand Assay $25: 167-177,2002$.

17. Koek HL, Grobbee DE, Bots ML. Trends in cardiovasculaire ziekte en sterfte in Nederland, 1980-2000. Ned Tijdschr Geneesk 148: 27-32, 2004.

18. Pelsers MMAL. Fatty acid-binding protein as plasma marker for tissue injury. Proefschrift, Universiteit Maastricht, 23 juni 2004.

19. GISSI investigators. Effectiveness of intravenous thrombolytic treatment in acute myocardial infarction. Lancet I: 397-402, 1986.

20. ISIS-2 Study Group. Randomised trial of intravenous streptokinase, oral aspirin, both, or neither among 17,187 cases of suspected acute myocardial infarction: ISIS-2. Lancet II: 349-360, 1988.

21. Kromhout D. Fish consumption, $\mathrm{N}-3$ fatty acids and coronary heart disease. In: Coronary heart disease epidemiology: From aetiology to public health. Marmot $M$, Elliott $P$ (Eds). Oxford University Press, 2004, in press.

22. Visscher TLS, Kromhout D. Seidell JC. Long-term and recent time trends in the prevalence of obesity among Dutch men and women. Int J Obesity 26: 1218$1224,2002$.

23. Dekker JM, Van der Kraan M, Nijpels G, De Vegt F, Kostense PJ, Stehouwer CDA, Bouter $L M$, Heine $R$. Schatting van het aantal nieuwe patiënten met diabetes mellitus type 2 in Nederland: ruim 65.000 per jaar in de leeftijdsgroep vanaf 50 jaar. Ned Tijdschr Ceneesk 147: 1419-1423. 2003.

24. Bonen A, Parolin ML, Steinberg GR, Calles-Escandon J, Tandon NN, Glatz JFC, Luiken JJFP, Heigenhauser GJ, Dyck DJ. Triacylglycerol accumulation in human obesity and type 2 diabetes is associated with increased rates of skeletal muscle fatty acid transport and increased sarcolemmal FAT/CD 36 . FASEB $J 18$ : $1144+1146,2004$.

25. Sambandam N, Lopaschuk GD, Brownsey RW, Allard MF. Energy metabolism in the hypertrophied heart. Heart Fail Rev 7: 161-173, 2002. 
26. Sodi-Pallares D, Testelli MR, Fishleder BL, Bisteni A, Medrano GA, Friedland C, De Micheli A. Effects of an intravenous infusion of a potassium-glucose-insulin solution on the electrocardiographic signs of myocardial infarction. Am J Cardiol 9: 166-181, 1962 .

27. Van der Horst IC, Zijlstra F, van't Hof AW, Doggen CJ, de Boer MJ, Suryapranata H. Hoorntje JC, Dambrink JH, Gans RO, Bilo HJ; Zwolle Infarct Study Group. Glucose-insulin-potassium infusion in patients treated with primary angioplasty for acute myocardial infarction: the glucose-insulin-potassium study: a randomized trial. J Am Coll Cardiol 42: 784-791, 2003.

28. Taegtmeyer H. Metabolism - the lost child of cardiology. J Am Coll Cardiol 36: $1386-1388,2000$.

29. Visser FC. Imaging of cardiac metabolism using radiolabelled glucose, fatty acids and acetate. Coron Artery Dis 12: S12-S18, 2001.

30. www.carim.unimaas.nl

31. De opleidingscommissie. In: Zelfstudie Geneeskunde 2003. Onderwijsinstituut Geneeskunde, Universiteit Maastricht, pp. 114-115, 2003.

32. Van missie naar koers. Strategisch programma van de Universiteit Maastricht 2002 - 2005, pp. 20-21.

33. Dr. Bart Dekker, eerste medisch directeur NHS. In: Een eeuw hart- en vaatziekten in Nederland (Klaassen A, Manger Cats V, Van der Wall EE, Heshusius $M$, eds). Nederlandse Hartstichting en Nederlandse Vereniging voor Cardiologie, pp. 190-195, 2004.

34. Lagarde $M$, Geloen $A$, Record $M$, Vance $D$, Spener $F$. Lipidomics is emerging. Biochim Biophys Acta 1634: 61, 2003.

35. Wilson JF. Long-suffering lipids gain respect. Scientist 17: 34-36, 2003. 


\section{Curriculum vitae}

Jan Glatz (1955) studeerde biochemie aan de universiteiten van Nijmegen en Utrecht, en promoveerde in 1983 te Nijmegen op een proefschrift over de regulatie van het vetzuurmetabolisme in hart- en skeletspier. Daarna werkte hij drie jaar als post-doc bij de vakgroep Humane Voeding van de toenmalige Landbouwuniversiteit te Wageningen, en bestudeerde daar waarom bij bepaalde mensen het bloedcholesterolgehalte sterk wordt beïnvloed door voedingsbestanddelen zoals verzadigd vet en cholesterol, terwijl anderen daar nauwelijks gevoelig voor zijn. In 1986 stapte hij over naar de Rijksuniversiteit Limburg, thans Universiteit Maastricht, en werd aangesteld bij de capaciteitsgroep Fysiologie (Faculteit der Ceneeskunde). In 1990 volgde zijn registratie als medisch fysioloog. In de periode 1991 - 1995 was hij Established investigator van de Nederlandse Hartstichting. Sinds 2003 werkt dr. Glatz bij de capaciteitsgroep Genetica \& Celbiologie, sectie Moleculaire Genetica. Per 1 december 2003 werd hij benoemd tot Hartstichtingshoogleraar. Hij was al (sinds 1999) Affiliated Professor aan de University of Guelph, Guelph, Canada.

Binnen het Cardiovascular Research Institute Maastricht (CARIM) doet $d r$. Glatz onderzoek naar de regulatie van het energiemetabolisme van de hartspier. Met zijn onderzoeksgroep ontdekte hij een nieuw mechanisme waarmee hartspiercellen de opname van vetzuren kunnen regelen. Ook ontdekte hij dat dit regelmechanisme is verstoord in het diabete hart. Naast dit fundamentele onderzoek is een andere onderzoekslijn opgezet waarin een nieuwe bloedtest voor de zeer vroegtijdige diagnose van een hartinfarct is ontwikkeld.

Dr. Glatz is (co-)auteur van $>200$ wetenschappelijke publicaties en (co-)organisator van vele internationale congressen. Verder is hij lid van de editorial board van enkele wetenschappelijke tijdschriften (o.a. Journal of Lipid Research en Obesity Research), en lid van het bestuur van de International Conferences on the Bioscience of Lipids (ICBL) en het bestuur van de International Society for the Study of Fatty Acids and Lipids (ISSFAL). 
